\title{
Pengaruh Dinamika Lingkungan Bisnis Terhadap Pengambilan Keputusan Terkait Sistem Pengendalian Manajemen Yang Ada di UD Mega Jaya
}

\author{
Meiliawati \\ Jurusan Akuntansi Fakultas Bisnis dan Ekonomika Universitas Surabaya \\ xiaoqing1405@gmail.com
}

\begin{abstract}
Abstrak - Dalam suatu perusahaan, sangatlah penting bagi pemimpin untuk dapat mengenal dan memahami dengan cermat mengenai keadaan yang ada di dalam (internal) dan di luar (eksternal) perusahaan. Salah satu faktor internal yang memiliki pengaruh penting dalam pencapaian tujuan perusahaan adalah sistem pengendalian manajemen sebagai pedoman bagi karyawan dalam melaksanakan pekerjaannya. Sedangkan faktor eksternal yang ada di luar perusahaan adalah lingkungan bisnis perusahaan yang seringkali mengalami perubahan dan bersifat turbulen. Penelitian ini mencoba mengungkap bagaimana lingkungan bisnis yang dinamis ini akan mempengaruhi penerapan sistem pengendalian manajemen yang ada di dalam suatu perusahaan keluarga. Hasil penelitian menunjukkan bahwa dinamika lingkungan sosial dan hukum, perekonomian, persaingan dan globalisasi, serta lingkungan teknologi ini dapat mempengaruhi keputusan pemimpin terkait dengan penetapan atau pengubahan terhadap alat sistem pengendalian manajemen yang ada, walaupun pada bentuk pengendalian manajemen tertentu, perubahan-perubahan tersebut akan memberikan dampak dalam jangka panjang.
\end{abstract}

Kata kunci: sistem pengendalian manajemen, lingkungan bisnis, bisnis keluarga, dinamika lingkungan bisnis

Abstract - In an enterprise, it is very important for a leader to know and understand carefully regarding the condition inside (internal) and outside (external) of the companies. One of the internal factors that have an important influence on the objectives achievement of the company is management control system as a guide for the employees to do their jobs. While external factors that are outside the company's business environment often subjected to changes and turbulent nature. This research tries to unravel how this dynamic business environment will affect the implementation of management control systems that exist within a family business. The results showed that the dynamics of the social and legal environment, the economy, competition and globalization, as well as the technology may affect the decision of leaders associated the existing management control system, although in the form of certain management control, these changes will give the impact in the long run.

Keywords: management control system, business environment, family business, dynamics of business environment 


\section{PENDAHULUAN}

Tidak dapat dipungkiri bahwa dalam suatu perusahaan, para karyawan yang merupakan sumber daya manusia adalah intangible asset yang paling penting. Bagaimana tidak, manusia merupakan perencana sekaligus pelaku aktivitas yang kinerjanya akan menentukan keberhasilan ataupun kegagalan perusahaan (Merchant dan Van der Stede, 2003; Efferin dan Soeherman, 2010). Oleh karena manusia memiliki sifat yang unik dan harapan yang berbeda-beda satu sama lainnya, dibutuhkan sistem pengendalian manajemen untuk dapat memastikan agar keinginan dan harapan karyawan sesuai dengan tujuan perusahaan.

Selain memperkokoh sistem pengendalian manajemen yang merupakan faktor internal perusahaan, pemimpin juga harus cermat dalam menanggapi adanya lingkungan di mana bisnis berada yang senantiasa dinamis karena bagaimanapun juga sebuah bisnis merupakan bagian dari society (Lawrence dan Weber, 2010). Adanya perubahan terhadap perubahan lingkungan bisnis ini membutuhkan penanganan yang spesifik, karena sebagian besar dari perubahan tersebut ada di luar kendali perusahaan (Efferin dan Handrian, 2010) dan dapat memunculkan baik peluang maupun ancaman bagi perusahaan (Lawrence dan Weber, 2010; Efferin dan Soeherman, 2010). Bagi perusahaan yang dinamis dan dapat memanfaatkan perubahan yang terjadi sebagai suatu peluang baru, maka perusahaan akan mendapatkan keuntungan, namun sebaliknya bagi perusahaan yang cenderung statis, maka perubahan akan menjadi suatu ancaman bagi kelangsungan hidupnya. Lingkungan eksternal serta bisnis ini sendiri akan saling memberikan pengaruh yang sifatnya resiprokal (Brooks dan Weatherston, 2000; Lawrence dan Weber, 2010).

Adanya keterkaitan antara perubahan lingkungan bisnis terhadap pengimplementasian SPM inilah yang menjadi topik yang sangat menarik untuk diteliti. Pada penelitian sebelumnya, Chenhall (2003) yang menyajikan suatu review kritis mengenai berbagai penemuan dari sejumlah studi dalam kurun waktu 20 tahun mengenai hubungan SPM dengan berbagai dimensi lingkungan organisasional yang mempengaruhinya secara kompleks, penelitian ini lebih 
berfokus pada bagaimana pengambilan keputusan yang dilakukan manajemen perusahaan dalam pengaruhnya terhadap dinamika lingkungan bisnis yang ada. Efferin dan Handrian (2010) juga menunjukkan betapa lingkungan bisnis yang dinamis telah mempengaruhi proses penganggaran serta penilaian kinerja dalam suatu perusahaan.

Dalam penelitian ini, objek penelitian yang dipilih merupakan perusahaan keluarga yang menganut budaya Tionghoa yang kental. Pada perusahaan keluarga UD Mega Jaya, adanya dinamika lingkungan bisnis telah membuat pemimpin melakukan beberapa penyesuaian terhadap sistem pengendalian manajemen yang ada sehingga penerapan SPM sekarang terkesan lebih dinamis dan fleksibel terhadap adanya perubahan lingkungan bisnis yang dinamis. UD Mega Jaya sendiri merupakan perusahaan yang bergerak di industri material sandal, sepatu, serta tas di Surabaya dan telah berdiri dan dikuasai oleh Keluarga Njoo sejak tahun 1990.

Penelitian ini berfokus untuk mengungkapkan serta menjelaskan dampak dari adanya dinamika lingkungan bisnis dalam bidang sosial dan hukum, perekonomian, persaingan dan globalisasi, serta teknologi terhadap pengambilan keputusan terkait pengendalian manajemen dan digunakan untuk kepentingan pengembangan teori yang telah ada sebelumnya.

Teori yang digunakan dalam penelitian ini adalah teori-teori dasar mengenai sistem pengendalian manajemen beserta bentuk penerapannya dalam perusahaan, termasuk pengendalian hasil yang berfokus pada output yang terukur, pengendalian proses yang berfokus pada proses yang dilalui, pengendalian personil yang berfokus pada pengendalian pribadi karyawan serta pengendalian budaya yang menekankan budaya organisasi sebagai alat pencegah bagi karyawan agar tidak melakukan hal-hal yang tidak diharapkan oleh perusahaan (Anthony dan Govindarajan, 2001; Merchant dan Van der Stede, 2003; Efferin dan Soeherman, 2010). Selain itu, penelitian ini juga menggunakan gabungan teori mengenai lingkungan bisnis beserta dinamikanya yang dikemukakan oleh Brooks dan Weatherston (2000) serta Lawrence dan Weber (2010) yang menjelaskan 
adanya dinamika pada lingkungan bisnis etika, sosial, alam, ekonomi, persaingan, globalisasi, hukum (legal) serta teknologi.

\section{METODE PENELITIAN}

Penelitian ini merupakan penelitian dengan pendekatan interpretifkualitatif dan dilakukan dalam kurun waktu 2,5 bulan. Ada dua metode pengumpulan data yang digunakan dalam penelitian ini, yaitu dengan melakukan interview serta observasi lapangan.

Selama bulan September 2012, peneliti telah berhasil melakukan wawancara dengan total 8 narasumber yang termasuk owner, kepala gudang, mandor, karyawan teknis, karyawan administratif, serta sales administrative dalam 14 sesi berbeda dan menghabiskan waktu total 16 jam (tabel 1). Seluruh proses wawancara dilakukan secara semi-terstruktur menggunakan pertanyaan yang memungkinkan narasumber untuk menjawab secara bebas berdasarkan pandangan serta opini pribadi mereka sendiri.

Tabel 1. Ringkasan Wawancara

\begin{tabular}{|c|c|c|c|}
\hline Narasumber & Keterangan kedudukan & $\begin{array}{c}\text { Total waktu } \\
\text { (jam) }\end{array}$ & Total sesi \\
\hline $\begin{array}{l}\text { Pemilik UD Mega Jaya (Bp. } \\
\text { Njoo Tjong Teng, usia } 44 \\
\text { tahun) }\end{array}$ & $\begin{array}{l}\text { Owner (pengambil } \\
\text { keputusan terutama urusan } \\
\text { strategis) }\end{array}$ & 7 & 4 \\
\hline $\begin{array}{l}\text { Istri pemilik (Ibu Mellissa, } \\
\text { usia } 41 \text { tahun) }\end{array}$ & $\begin{array}{l}\text { Owner (pengambil } \\
\text { keputusan terutama urusan } \\
\text { operasional) }\end{array}$ & 3,5 & 3 \\
\hline $\begin{array}{l}\text { Kepala Gudang (Bp. Felix } \\
\text { Mahendra, usia } 48 \text { tahun) }\end{array}$ & $\begin{array}{l}\text { Kakak laki-laki dari Ibu } \\
\text { Mellissa selaku owner }\end{array}$ & 0,5 & 1 \\
\hline $\begin{array}{l}\text { Mandor (Bp. Sampono, usia } \\
48 \text { tahun) }\end{array}$ & $\begin{array}{l}\text { Karyawan yang telah } \\
\text { mengabdi selama } 28 \text { tahun } \\
\text { di UD Mega Jaya }\end{array}$ & 1,5 & 2 \\
\hline $\begin{array}{l}\text { Salesperson (Bp. Andrew, } \\
\text { usia } 37 \text { tahun) }\end{array}$ & $\begin{array}{l}\text { Karyawan dengan gaji } \\
\text { bulanan ditambah dengan } \\
\text { komisi penjualan }\end{array}$ & 1 & 1 \\
\hline $\begin{array}{l}\text { Karyawan teknis (Bp. } \\
\text { Madechan, usia } 39 \text { tahun) }\end{array}$ & $\begin{array}{l}\text { Karyawan dengan upah } \\
\text { harian }\end{array}$ & 1 & 1 \\
\hline $\begin{array}{l}\text { Karyawan administratif (Ibu } \\
\text { Denok, usia } 26 \text { tahun) }\end{array}$ & $\begin{array}{l}\text { Karyawan dengan gaji } \\
\text { bulanan }\end{array}$ & 1 & 1 \\
\hline $\begin{array}{l}\text { Karyawan administratif (Ibu } \\
\text { Wahyu, usia } 39 \text { tahun) }\end{array}$ & $\begin{array}{l}\text { Karyawan dengan gaji } \\
\text { bulanan }\end{array}$ & 0,5 & 1 \\
\hline \multicolumn{2}{|c|}{$\begin{array}{ll}\text { Total } \\
\end{array}$} & 16 & 14 \\
\hline
\end{tabular}


Untuk observasi non-partisipan yang dilakukan, peneliti membutuhkan waktu selama kurang lebih 1 bulan selama bulan September 2012 untuk memperoleh data-data pendukung dari wawancara yang telah dilakukan sehingga dapat meminimalisasi bias. Observasi dilakukan selama jam operasional perusahaan dan dilakukan di toko dan gudang dengan mengumpulkan data dari aktivitas sehari-hari perusahaan, situasi kerja yang mencerminkan hubungan antara atasan dan bawahan, serta kegiatan-kegiatan lain yang mendukung untuk mendapatkan hasil penelitian yang akurat.

\section{HASIL DAN PEMBAHASAN}

\section{Sistem Pengendalian Manajemen}

Dalam UD Mega Jaya, ada empat bentuk pengendalian yang diterapkan, yaitu pengendalian hasil, proses, personil, serta budaya. Dalam pengendalian hasil, pemimpin mencoba untuk memberikan suntikan semangat terhadap karyawan, khususnya bagian penjualan dengan pemberian insentif atau bonus tambahan ketika karyawan tersebut berhasil mencapai target yang telah ditetapkan sebelumnya. Dalam kegiatan yang ada sehari-hari di UD Mega Jaya, pengendalian proses terlihat dalam adanya pembatasan perilaku secara fisik dan administratif, proses prakendali sebelum karyawan secara langsung berhadapan dengan pelanggan, serta penerapan action accountability yang dilakukan agar seluruh karyawan selalu mau bertanggung jawab terhadap setiap perbuatan yang telah mereka lakukan.

Selain kedua pengendalian tersebut, UD Mega Jaya juga senantiasa memberikan training terhadap karyawan yang baru saja mulai bekerja sebagai bentuk adanya pengendalian personil. Budaya dalam perusahaan keluarga merupakan cerminan dari nilai-nilai keluarga pemimpin. Dalam UD Mega Jaya sendiri, pemimpin mencoba untuk mempertegas pengendalian budaya berdasarkan nilai-nilai keluarga pemimpin dengan memberikan social arrangement berupa pakaian kerja yang bertuliskan identitas perusahaan serta memberikan contoh nyata bagi karyawan dalam melakukan suatu pekerjaan sesuai dengan prinsip yang dianut (tone at the top). 
Keempat bentuk pengendalian manajemen tersebut diterapkan di UD Mega Jaya dengan metode yang disebut oleh pemimpin merupakan metode 'tarikulur' untuk dapat mengendalikan para karyawan yang memiliki keinginan yang berbeda-beda satu sama lain.

“Bawahan itu jangan dimelok'i (diikuti) terus. Mereka harus dilepas, biar lambat laun mereka bisa berdiri dan jalan sendiri. Dengan catatan, kontrol ya harus tetep ada. Kita orang ya musti harus tetep kontrol, tapi ya nda perlu terlalu ketat sampe kaya gimana gitu.” (Bp. Njoo Tjong Teng)

"Ya itulah yang namanya di'tarik-ulur' ya itu. Jadi kadang ya dikencengi (diperketat), tapi kadang ya dilonggari.” (Ibu Mellissa)

Strategi ini dipercaya oleh pemilik dapat membuat para karyawan bekerja dengan baik. Mereka akan dapat bekerja dengan baik dan nyaman, tanpa mengurangi rasa hormat kepada atasan mereka. Nuansa kekeluargaan dapat membuat karyawan menjadi nyaman, kebebasan bagi karyawan juga dapat membuat karyawan menjadi lebih ulet, serta pencukupan kebutuhan karyawan melalui pengendalian hasil juga akan sangat efektif untuk memacu semangat kerja semua karyawan sehingga hasil yang dicapai juga menjadi jauh lebih bagus.

\section{Dinamika Lingkungan Bisnis}

Ketika perusahaan dihadapkan dengan dinamika lingkungan bisnisnya, maka pemimpin harus dengan cepat mengambil keputusan taktis terkait pengendalian manajemen untuk mencegah terjadinya risiko berupa control cost dari perubahan lingkungan bisnis yang tidak dapat dikendalikan tersebut. Dalam UD Mega Jaya, beberapa lingkungan bisnis yang sangat berpengaruh dalam setiap proses dan kegiatan yang dilakukan adalah lingkungan sosial dan hukum, perekonomian, persaingan dan globalisasi, serta lingkungan teknologi yang belakangan ini semakin berkembang pesat. Dalam lingkungan sosial dan hukum, perusahaan dihadapkan pada tuntutan masyarakat untuk memberlakukan sistem kerja tetap karena adanya sistem kerja kontrak dirasa masyarakat telah sangat merugikan pihak karyawan. Selain masyarakat, pemerintah juga menuntut agar 
perusahaan dapat memberikan upah dan gaji yang nilainya di atas standar upah minimum yang ditetapkan daerah.

Dalam bidang perekonomian, tuntutan karyawan terhadap perusahaan untuk memberikan kenaikan gaji ketika harga bahan bakar naik dan Tunjangan Hari Raya (THR) tiap tahunnya akibat adanya inflasi dari tahun ke tahun juga membuat pemimpin mencoba untuk mengevaluasi kembali sistem pengendalian manajemen yang diterapkan seperti yang terlihat dalam kutipan wawancara dengan owner berikut.

“Mereka itu cepet sekali. Ada bensin mundak titik ae lho, langsung njaluk mundhak bayarane (minta naik bayarannya). Wes unjuk rasa kabeh sudahan, mulai ngoceh kabeh. Kalo wes gitu, celuk endas'e (panggil kepalanya - mandor). Maunya apa? Minta naik berapa? Kita juga ga harus nuruti kemauan mereka, tapi musti kita itung dulu. Dan aku tanya juga, kalo aku mau bayar kamu segitu, konsekuensinya kamu ke aku gimana. Itu semua harus diomongkan biar bisa dikendalikan. Nah kalo aku bayar kamu segitu, tapi kerjoanmu tetep sak gitu, yo ga iso. Harus lebih giat lagi.” (Ibu Mellissa)

Perekonomian nampaknya merupakan hal yang sangat sensitif bagi para karyawan serta dapat mempengaruhi kinerja mereka. Seperti yang diakui oleh pemimpin bahwa ketika tuntutan akibat perubahan yang ada dalam bidang perekonomian belum mendapatkan tanggapan dari atasan, maka para karyawan akan mengalami penurunan kinerja. Hal inilah yang membuat pemimpin akan dengan cepat dan tanggap mengambil keputusan ketika dihadapkan pada situasi yang demikian.

Lingkungan persaingan dan globalisasi masing-masing juga menimbulkan suatu peluang dan ancaman tersendiri bagi perusahaan dan membuat pemimpin harus melakukan perubahan terhadap penerapan pengendalian manajemen yang telah ada. Misalnya saja, dalam kondisi persaingan yang sangat ketat, pemimpin akan mencoba memberikan motivasi tambahan bagi para karyawan untuk dapat terus meningkatkan penjualan dalam keadaan yang demikian. Globalisasi juga menawarkan banyak sekali peluang baru dimana perusahaan akan dapat memperoleh pangsa pasar baru dengan banyaknya importir-importir baru yang mencoba memasuki pasar Indonesia. Sedangkan 
untuk lingkungan teknologi yang sedang mengalami perkembangan yang sangat pesat, pemimpin juga dituntut untuk secara cerdas mengambil keputusan dan memanfaatkan kemajuan teknologi yang ada untuk mengurangi biaya operasional serta meningkatkan pendapatan perusahaan.

\section{Dinamika Lingkungan Bisnis terhadap Sistem Pengendalian Manajemen}

Di UD Mega Jaya, adanya dinamika lingkungan sosial dan hukum, perekonomian, persaingan dan globalisasi, serta teknologi telah memberikan pengaruh bagi pemimpin dalam proses pengambilan keputusan terkait sistem pengendalian manajemen yang ditetapkan. Tabel 2 berikut merupakan uraian singkat bagaimana perubahan dalam lingkungan bisnis memberikan dampak terhadap pengendalian hasil, proses, serta personil. 
Tabel 2. Pengaruh Dinamika Lingkungan Bisnis terhadap SPM UD Mega Jaya

\begin{tabular}{|c|c|c|c|c|}
\hline SPM Lingkungan & Sosial dan Hukum & Perekonomian & Persaingan dan Globalisasi & Teknologi \\
\hline Result Control & & $\begin{array}{l}\text { - Dalam kondisi perekonomian } \\
\text { yang turbulen, pemimpin } \\
\text { mencoba untuk meningkatkan } \\
\text { motivasi para karyawan } \\
\text { dengan memberikan bonus } \\
\text { tambahan ketika karyawan } \\
\text { berhasil mencapai target } \\
\text { penjualan tertentu yang telah } \\
\text { ditetapkan sebelumnya oleh } \\
\text { pemimpin } \rightarrow \text { adanya } \\
\text { pengetatan penerapan result } \\
\text { control }\end{array}$ & $\begin{array}{l}\text { - Ketika menghadapi tantangan } \\
\text { persaingan dan globalisasi } \\
\text { yang cukup berat, maka } \\
\text { perusahaan akan mencoba } \\
\text { menerapkan pengendalian } \\
\text { hasil (result control) dalam } \\
\text { bentuk insentif serta bonus- } \\
\text { bonus tambahan sebagai } \\
\text { penambah motivasi karyawan } \\
\text { ketika karyawan berhasil } \\
\text { meningkatkan kinerja sesuai } \\
\text { dengan target yang ditentukan }\end{array}$ & \\
\hline Action Control & $\begin{array}{l}\text { - Penerapan pengendalian } \\
\text { proses dalam bentuk action } \\
\text { accountability yang lebih } \\
\text { ketat ketika memberlakukan } \\
\text { sistem karyawan tetap, bukan } \\
\text { kontrak } \rightarrow \text { dengan menjadi } \\
\text { karyawan tetap, para } \\
\text { karyawan dituntut untuk dapat } \\
\text { lebih bertanggung jawab } \\
\text { terhadap kinerja yang } \\
\text { berkontribusi bagi perusahaan }\end{array}$ & $\begin{array}{l}\text { - Penerapan pengendalian } \\
\text { proses dalam bentuk } \\
\text { pertanggungjawaban terhadap } \\
\text { pekerjaan yang dilakukan } \\
\text { (action accountability) yang } \\
\text { lebih ketat sebagai bentuk } \\
\text { timbal balik yang dituntut } \\
\text { oleh pemimpin karena } \\
\text { pemimpin bersedia untuk } \\
\text { menaikkan gaji dan upah } \\
\text { akibat kenaikan harga BBM }\end{array}$ & $\begin{array}{l}\text { - Ketika perusahaan dihadapkan } \\
\text { pada lingkungan persaingan } \\
\text { yang dinamis, perusahaan } \\
\text { akan memperketat } \\
\text { pengendalian proses yang } \\
\text { dilakukan dalam bentuk } \\
\text { proses prakendali (preaction } \\
\text { reviews) sebagai pedoman } \\
\text { bagi para karyawan dalam } \\
\text { menghadapi persaingan } \\
\text { - Memasuki era globalisasi, } \\
\text { perusahaan akan mencoba } \\
\text { untuk memanfaatkan peluang } \\
\text { yang ada dengan memperketat } \\
\text { pengendalian proses dalam } \\
\text { bentuk proses prakendali } \\
\text { (preaction reviews) sebagai } \\
\text { arahan bagi para karyawan } \\
\text { ketika mempromosikan } \\
\text { produk impor baru }\end{array}$ & $\begin{array}{l}\text { - Adanya penerapan } \\
\text { pengendalian proses yang } \\
\text { lebih ketat dalam bentuk } \\
\text { behavioral constraints } \\
\text { dengan melakukan } \\
\text { pemasangan CCTV untuk } \\
\text { dapat melakukan pengawasan } \\
\text { intensif sebagai tanggapan } \\
\text { dari adanya kemajuan } \\
\text { teknologi yang lebih mudah, } \\
\text { efektif, dan efisien }\end{array}$ \\
\hline
\end{tabular}




\begin{tabular}{|l|l|l|l|}
\hline & - Adanya perubahan pada lebih & - Selain berdampak pada & \\
& ketatnya pengendalian & pengendalian proses, \\
& personil, yaitu selection and & keputusan pemimpin untuk & \\
placement $\rightarrow$ pemberian upah & memberikan gaji dan upah di & \\
& dan gaji yang nominalnya di & atas standar minimum yang \\
& atas UMR setempat membuat & ditentukan pemerintah serta & \\
& adanya kebijakan perusahaan & menetapkan kenaikan THR & \\
Personnel Control & dengan memberlakukan & tiap tahunnya juga telah & \\
& sistem penyeleksian bagi & membuat pengendalian & \\
& calon karyawan baru dengan & personil yang dilakukan & \\
& lebih ketat & menjadi semakin ketat $\rightarrow$ para & \\
& & karyawan dituntut untuk dapat & \\
& & mematuhi sistem dan prosedur & \\
& & yang berlaku di UD Mega & \\
& & Jaya menunjukkan adanya & \\
& pengendalian personil yang & lebih ketat ketika proses \\
& selection and placement & \\
\hline
\end{tabular}


Ketika terjadi dinamika pada lingkungan sosial dan hukum, misalnya mengenai permasalahan outsourcing, pemimpin mempertimbangkan apabila praktik tersebut coba diterapkan di UD Mega Jaya. Melalui pertimbangan mengenai bagaimana respon dari para karyawan UD Mega Jaya dan aspek finansial yang sangat terpengaruh oleh kebijakan tersebut, maka pemimpin memutuskan untuk tetap memberlakukan sistem kerja tetap dengan masa percobaan selama satu tahun untuk karyawan baru yang merupakan salah satu bentuk action control. Pengendalian proses yang diterapkan dapat dilihat dari adanya peningkatan action accountability sebagai timbal balik dari karyawan atas kebijakan perusahaan tersebut.

Lingkungan sosial dan hukum juga mewajibkan penetapan gaji dan upah di atas tingkat upah minimum regional (UMR) suatu daerah. Sebagi tanggapan atas tuntutan tersebut, UD Mega Jaya memberikan gaji dan upah yang telah melebihi tingkat UMR kota Surabaya terbaru (sebesar Rp 1.257.000). Dari sini juga terlihat bahwa adanya dinamika lingkungan sosial dan hukum telah berdampak pada penetapan personnel control berupa adanya proses selection and placement yang lebih ketat dari sebelumnya karena pemimpin juga mengharapkan dengan mengeluarkan biaya yang lebih tinggi bagi karyawan, maka pemimpin menginginkan karyawan yang kinerjanya juga lebih berkualitas dalam melakukan tanggung jawab pekerjaannya.

Pertimbangan pemimpin UD Mega Jaya untuk memberikan tingkat upah yang termasuk tinggi karena adanya ketentuan hukum yang melindungi hak karyawan dengan mewajibkan pengusaha untuk memberikan upah setidaknya sama dengan UMR daerah tersebut. Selain itu, menurut pengakuan pemimpin UD Mega Jaya apabila dilihat dari aspek ekonominya, pemberian gaji dan upah merupakan aspek yang sangat sensitif bagi para karyawan. Pemimpin meyakini bahwa faktor finansial adalah faktor yang mendasari seorang karyawan untuk mau bekerja, dan semakin besar yang diberikan perusahaan terhadap para karyawannya, maka semakin besar pula timbal balik yang akan diberikan oleh karyawan tersebut. 
Dinamika lingkungan perekonomian juga sangat berpengaruh pada penetapan SPM di UD Mega Jaya terkait dengan kenaikan harga BBM yang berimbas pada permintaan para karyawan untuk diberikannya suatu kenaikan upah dan gaji. Pemimpin menjelaskan bahwa perubahan sedikit saja yang terjadi pada aspek ekonomi ini, misalnya pemerintah menetapkan bahwa per tanggal 1 bulan depan, harga BBM akan naik, maka karyawan akan mulai menggerutu meminta kenaikan gaji dan upah yang disampaikan melalui mandor. Sebelum permintaan tersebut dikabulkan, maka semangat kerja karyawan akan mulai menurun. Dari sini dapat dilihat bahwa faktor ekonomi merupakan faktor lingkungan bisnis yang paling sensitif dan cenderung membutuhkan pengambilan keputusan yang relatif cepat.

Faktor inflasi di Indonesia juga menjadi salah satu faktor lingkungan perekonomian lain yang membuat pemimpin UD Mega Jaya selalu memberikan adanya kenaikan gaji/upah serta THR dari tahun ke tahun. Semua hal di atas telah memberikan bukti bahwa adanya dinamika lingkungan perekonomian memiliki dampak yang sangat signifikan terhadap pengambilan keputusan terkait action control berupa action accountability dimana pemimpin mau melakukan kenaikan gaji, namun dengan konsekuensi bahwa para karyawan harus meningkatkan kinerjanya.

Dari fakta di atas dapat dilihat bahwa pemimpin menginginkan adanya timbal balik atas manfaat yang telah diberikan kepada karyawan dalam bentuk peningkatan kinerja para karyawan itu sendiri. Selain itu, pemimpin juga menerapkan adanya pemberian bonus dan insentif tambahan ketika karyawan berhasil mencapai suatu target tertentu akan mengakibatkan motivasi para karyawan kembali meningkat dan akan secara signifikan berdampak pada kinerja karyawan tersebut. Selain itu, karena pemimpin telah mau mengikuti standar perekonomian yang ada dengan mempertimbangkan inflasi untuk menetapkan kenaikan gaji, maka pemimpin tentu mengharapkan karyawan yang semakin baik kualitasnya sehingga proses selection and placement yang termasuk bentuk pengendalian personil akan semakin ketat dalam penerapannya. 
Terjadinya perubahan dalam lingkungan persaingan bisnis akan mempengaruhi SPM dari sisi ketat atau tidaknya SPM tersebut diberlakukan oleh pimpinan. Pimpinan juga akan berusaha untuk memberikan semangat dan motivasi melalui berbagai cara agar karyawan tetap dapat mencapai tingkat penjualan yang ditargetkan meskipun harga sedang anjlok di pasaran. Motivasi tersebut dapat biasanya berupa pemberian bonus-bonus (black bonus) apabila target telah berhasil dicapai.

Memanfaatkan peluang di era globalisasi merupakan salah satu kunci untuk dapat memenangkan persaingan. Dorongan akan diberikan dalam bentuk materi maupun non-materi untuk dapat membuat penjualan mencapai tingkat penjualan yang telah ditargetkan oleh pimpinan. Dengan demikian, adanya perubahan terhadap lingkungan persaingan serta globalisasi juga berdampak pada dua bentuk SPM UD Mega Jaya, yaitu result control serta action control berupa preaction reviews.

Selain faktor-faktor di atas, adanya dinamika lingkungan teknologi juga telah memberikan alternatif penetapan SPM baru yang cukup efektif, ekonomis, dan efisien di UD Mega Jaya. Pemimpin mengambil keputusan untuk melakukan pemasangan CCTV guna memperketat pengawasan terhadap kinerja para karyawan. Dengan memasang CCTV pada area yang ingin diawasi, maka hal ini tentu akan menyulitkan bagi karyawan yang ingin melakukan suatu penyimpangan atau pelanggaran. Dengan demikian, adanya kemajuan teknologi sebagai salah satu dinamika lingkungan teknologi juga berimbas terhadap action control berupa pembatasan perilaku (behavioral constraints) yang dilakukan oleh pemimpin terhadap para karyawan dimana pemimpin dapat melakukan kegiatan pengawasan secara lebih mudah dan efektif.

Dari tabel 2 di atas, dapat dilihat bahwa secara langsung dinamika lingkungan bisnis yang ada tidak memberikan pengaruh bagi pengendalian budaya yang ada. Hal ini disebabkan oleh esensi dari budaya organisasi yang memang baru dapat terbentuk secara turun-temurun dan baru terbentuk atau mengalami perubahan dalam waktu yang cukup lama. Budaya organisasi pada perusahaan keluarga terbentuk dari nilai-nilai keluarga pemimpin yang telah ada 
dari sebelum perusahaan berdiri. Jadi sebenarnya perihal pengendalian budaya ini memang tidak secara langsung dan dalam kurun waktu yang singkat terpengaruh oleh adanya perubahan dari lingkungan bisnis yang cenderung turbulen. Meskipun tidak dapat terpengaruh secara langsung, namun dalam kurun waktu yang lebih panjang, budaya organisasi juga akan mendapatkan efek secara tidak langsung dari adanya perubahan lingkungan bisnis yang tetap.

Dari uraian penjelasan di atas, dapat dilihat bagaimana pemimpin UD Mega Jaya telah mempertimbangkan adanya dinamika lingkungan bisnis yang terjadi dalam pengambilan keputusan terkait SPM yang ada. Oleh karena itu, apabila dibandingkan dengan kepemimpinan yang sebelumnya, kepemimpinan Bp. Njoo Tjong Teng terkesan lebih dinamis dan fleksibel terhadap perubahan yang ada seperti yang terekam dalam kutipan wawancara berikut.

"Kita orang ini sudah pake sistem modern, beda sama orang totok (Tionghoa) zaman dahulu. Kalo orang totok zaman dulu itu prinsipnya kalo bisa tenaga anak buah itu diperes (diperas) sebanyak-banyaknya, tapi bayarnya semurah-murahnya. Kalo prinsip modern sekarang ini sudah ganti. Sudah gak zamannya yg kaya gitu. Sekarang zamannya itu anak buah kita kasih suntikan dengan cara ya mereka dikasi bayaran yang setimpal. Pertimbangan kita, kalau mereka merasa kerja di sini enak, jadi mereka bakal anteng (tidak berulah). Kita orang percaya kalo kita orang bisa royal sama mereka, loyalitas mereka juga tinggi.” (Bp. Njoo Tjong Teng)

Dalam suatu perusahaan keluarga, seharusnya nilai-nilai keluarga pemimpinlah yang akan mendasari pembentukan gaya kepemimpinan dan budaya organisasi. Namun, seperti yang terlihat dalam UD Mega Jaya, pemimpin tidak hanya menggunakan nilai-nilai keluarga yang diyakini tersebut sebagai satusatunya pembentuk budaya organisasi. Pemimpin terkesan cenderung memasukkan unsur perubahan lingkungan bisnis yang ada ke dalam proses pengambilan keputusan sehingga keputusan yang diambil juga telah disesuaikan dengan kenyataan relevan yang sedang terjadi.

\section{KESIMPULAN DAN SARAN}

Perusahaan yang ingin tetap dapat bertahan dalam persaingan di industrinya, harus memberikan perhatian pada faktor internal dan eksternal 
perusahaan. Faktor internal yang sangat penting bagi sebuah perusahaan adalah sistem pengendalian manajemen yang merupakan dasar pengendalian internal dalam perusahaan dan akan memunculkan kekuatan dan kelemahan bagi perusahaan tersebut. Selain melihat faktor internal, pemimpin juga harus memperhatikan faktor eksternal berupa lingkungan bisnis yang juga sangat mempengaruhi kelangsungan perusahaan dan secara serta merta memunculkan peluang dan ancaman bagi kinerja perusahaan. Tidak terkecuali yang terjadi dalam perusahaan keluarga. Perusahaan keluarga yang cenderung sarat dengan penerapan nilai-nilai keluarga pemimpin terdahulu, juga dituntut untuk melakukan penyesuaian apabila ingin terus bertahan dalam persaingan bisnis masa kini dengan lingkungan binsis yang sangat dinamis. Dengan memasukkan pertimbangan keadaan lingkungan bisnis yang dinamis dalam pengambilan keputusannya, maka UD Mega Jaya dapat menciptakan alat pengendalian yang fleksibel, adaptif, efektif dan efisien terhadap para karyawannya.

\section{DAFTAR PUSTAKA}

Anthony, Robert N. Dan Vijay Govindarajan. 2001. Management Control Systems $10^{\text {th }}$ edition. McGraw-Hill: New York.

Brooks, Ian dan Jamie Weatherston. 2000. The Business Environment: Challenges and Changes $2^{\text {nd }}$ edition. Prentice-Hall: Harlow.

Chenhall, Robert H. 2003. Management Control System Design Within Its Organizational Context: Findings from Contingency-Based Research and Directions for The Future. Accounting, Organizations, and Society 28 pp. 127-168.

Efferin, Sujoko dan Arthur Handrian. 2010. Saling Peran antara Budgeting, Dinamika Lingkungan Bisnis, dan Konflik Internal: Studi Interpretif. Manajemen dan Bisnis, Vol 9 No 2 hal 161-187.

Efferin, Sujoko and Bonnie Soeherman. 2010. Seni Perang Sun Zi dan Sistem Pengendalian Manajemen: Filosofi dan Aplikasi. PT Gramedia: Jakarta.

Efferin, Sujoko dan Monika Setyowati Hartono. 2012. Management Control and Leadership Styles in Family Business. Paper presented at the $3^{\text {rd }}$ GAOC Conference, 14-17 July 2012, Sunway University, Malaysia.

Lawrence, Anne T. and James Weber. 2011. Business and Society: Stakeholders, Ethics, Public Policy. McGraw Hill: New York. 
Merchant, Kenneth A. dan Wim A. Van der Stede. 2003. Management Control Systems: Performance Measurement, Evaluation and Incentives. Prentice-Hall: Harlow.

Mulyadi, Hari. 2011. UMR/UMK Propinsi Jawa Timur, Non Sektor pada tahun 2012 (online). Available: www.hrcentro.com, diakses: 12 Oktober 2012. 